\title{
Algunas reflexiones sobre los congresos anuales de la AMEE
}

\author{
A. Wojtczak
}

En 1998, asistieron al congreso anual de la AMEE, celebrado en Praga, unos 400 participantes, procedentes en su mayor parte de países europeos, Canadá y Estados Unidos; 10 años después, en el congreso del año 2008, también en Praga, participaron más de 2.300 educadores médicos procedentes de 80 países. La AMEE, en principio una asociación europea, se ha convertido con el tiempo en un foro global para educadores médicos que atrae cada año a más y más educadores, procedentes de prácticamente todos los países, en particular de Oriente Medio y del continente asiático. Cabe destacar que un gran número de nuevos participantes procedían de Irán, Tailandia y Malasia. En Praga, el 60\% de los participantes lo eran por primera vez, ansiosos por aprender los nuevos avances en educación médica, con el fin de poderlos introducir en sus propios países para poder mejorar la calidad de su educación médica. Deseaban, asimismo, compartir con otros sus propias experiencias educativas y sus logros. Este rápido crecimiento de asistentes va ligado a un incremento en el número de comunicaciones. En consecuencia, los organizadores del congreso han incrementado el número de sesiones plenarias simultáneas y de grupos amplios, de discusiones en grupos reducidos, de talleres y de sesiones de paneles. Esto crea una situación en la que los participantes, sobre todo los que acuden por primera vez, van de un lado a otro, escuchando diversas presentaciones sobre experiencias llevadas a cabo con éxito y soluciones para diferentes problemas educativos. Sin embargo, el incremento del número de reuniones durante las pausas-café o durante el tiempo de las comidas limita los contactos personales y la posibilidad de intercambiar puntos de vista. Por otra parte, el aumento de participantes limita las posibilidades de encontrar países que puedan acoger el congreso, ya que se requiere disponer de un gran palacio de congresos. En principio, debe considerarse que este desarrollo de los congresos de la AMEE es extremadamente satisfactorio y estimulante para la asociación, pero nos preguntamos qué tipo de conocimientos y experiencias son capaces de adquirir los participantes y, sobre todo, cómo pueden usarlos eficazmente en su trabajo personal. No cabe duda de que es el precio a pagar por el rápido crecimiento del interés por la educación médica. Sin embargo, si la AMEE quiere influir en la educación médica de una forma global obligatoriamente debe pensar qué puede hacer para mejorar esta situación, e incrementar los beneficios educativos para sus participantes y permitirles que puedan llevarse con ellos algún conocimiento que pueda ser usado para mejorar la calidad del proceso educativo. La pregunta es: ¿qué se puede hacer para mejorar esta situación?

Hace dos años se tomó una decisión organizativa importante, la celebración antes de la sesión inaugural de la denominada 'sesión de orientación' diseñada para facilitar información a los nuevos participantes acerca de la historia de AMEE, de sus objetivos y actividades y sobre el programa del congreso, señalando los puntos de mayor importancia. Otro hecho importante es la denominada Spotlights session organizada al final de congreso con el fin de llevar a cabo un resumen de los resultados más importantes del mismo. Sin embargo, estos resúmenes dependen demasiado de los ponentes y muy a menudo reflejan más los propios puntos de vista que los resultados que se deducen de las presentaciones.
Exdirector del International Institute for Medical Education (IME)

Expresidente de la Association for Medical Education in Europe (AMEE) E-mail wojtczak@cmkp.edu.pl 
Creemos que es necesario desarrollar un modelo más estructurado para estos resúmenes haciendo hincapié en las implicaciones prácticas en la educación médica. Estas innovaciones son, sin duda, importantes, pero deberían considerarse más innovaciones de este tipo. Quisiéramos sugerir que se introdujeran al inicio de algunas sesiones unas presentaciones magistrales, que revisarían el 'estado del arte' de los enfoques más interesantes de la educación médica que se someterán a discusión y experimentación. Esto permitiría a los participantes escuchar de manera más crítica las diferentes presentaciones y juzgar más adecuadamente su pertinencia. Podrían citarse, como ejemplos de estos temas, la educación médica basada en los resultados, los métodos de evaluación de las habilidades clínicas y, especialmente, el profesionalismo, el aprendizaje basado en la solución de problemas o la educación médica basada en la comunidad por mencionar sólo algunos de ellos. Estas presentaciones sobre el 'estado del arte' de estos temas, impartidas por expertos en ellos, en las sesiones plenarias, podrían, dada la experiencia de los educadores, ayudar a comprender mejor las diferentes presentaciones, evitar interpretaciones erróneas y fallos al querer aplicarlos en sus propios países. Es nuestra obligación evitar la aceptación acrítica de numerosos experimentos atractivos, pero pobremente evaluados.

\section{Some reflections on the AMEE Annual Conferences}

When in 1998 AMEE Conference in Prague was attended by 400 participants mainly from European countries, Canada and the United States, 10 years later in 2008 the AMEE Conference in Prague was attended by over 2,300 medical teachers from about 80 countries. This primarily the European Association in a decade has became the global forum for medical educators attracting every year more and more teachers from literally all part of the world and in particular from Middle East and the Asian continent. It is interesting that a great number of new participants came from Iran, Thailand and Malaysia. In Prague about $60 \%$ of attendees were newcomers, eager to learn about new advances in medical education that could be introduced to improve the quality of education in their country. They also wanted to share with others their own educational experiences and achievements. This fast growing number of participants is associated with the increasing number of papers to be presented. Therefore, the conference organizers are setting growing number of simultaneous plenary and large group sessions, small group discussions, workshops and posters sessions. It creates situation in which the participants, especially those attending conference for the first time, are moving around, listening to various presentations on 'successful' experiences and solutions of different educational problems. Simultaneously, the growing number of different meetings during the coffees or lunch breaks is taking place what further is limiting the personal contacts and possibility of exchanging views. On top of that a growing number of attendees is limiting possibility of finding the country that can organize the conference as the first requirement is access to a big conference center. In principle, this development is extremely satisfying and encouraging for the AMEE executives, however one has to ask what kind of knowledge and experiences the attendees are able to take back home that can be effectively used in their work? No doubt this is the price of a fast growing interest in medical education. However, if AMEE wants to influence the medical education globally it is obligated to think what can be done to ameliorate this situation and to increase the educational gains of attendees and permit them to take back some knowledge to use it at home to improve the quality of educational process. The question is what can be done to ameliorate this situation?

An important organizational step was already taken two years ago, the organization before opening conference so call 'orientation session' that is designed for new attendees providing them information about AMEE history, tasks and scope of activities, and about conference program with an indication on the various points of greater importance. Another important event is so call 'Spotlights session' organized at the end of the conference with aim of summarizing most important outcomes. However, these summaries depend too much on the speakers and very often are reflecting their own views than the issues steaming up from the presentations. I feel that it is necessary to develop more structured pattern for these presentations with stress on some practical implication for process of medical education. These innovations 
are definitely the important steps, but we need to consider more such innovations. Here, I would like to suggest the introduction at the beginning of some sessions the 'master lectures' that would review the present 'state of art' of most interesting approaches to medical education that are under broad discussion and experimentation. It would enable the participants more critically listen to the various presentations and judge their pertinence. Such topics definitely is the outcome-oriented education, the methods of assessment of clinical skills and especially professionalism, the problem based learning (PBL), or community-oriented medical education to mention few. Such 'state of art' lectures delivered by the experts in a given aspect of medical education at the plenary sessions by the experience educators could help to better comprehend the various presentations, avoiding misunderstanding and then failures in implementations when back in own countries. It is our obligation to prevent uncritical accepting many attractive but poorly evaluated educational experiments. 